\title{
Characterization of Mohanthal -A traditional sweet from Gujarat, India
}

\author{
MB Chaudhary, K Jayaraj Rao and Harin Sutariya
}

Received: 12 February 2020 / Accepted: 14 April 2020 / Published online: 12 July 2020

(C) Indian Dairy Association (India) 2020

\begin{abstract}
Mohanthal is a popular sweet consumed in Gujarat state of India. In order to characterize the typical attributes of this traditional sweet, samples were collected from Ahmedabad, Anand, Vadodara and Palanpur cities of Gujarat and evaluated for sensory, physico-chemical, textural and microbiological characteristics. Wide variations in the composition of the market samples were found to exist. Moisture, fat, protein, lactose, sucrose, ash, other carbohydrates and free fatty acid contents of the market samples were in the range of 8.64-13.86, 18.21-28.12, $8.27-13.00,0.00-12.10,19.00-29.56,0.81-1.81,17.61-32.95 \%$ and $0.85-1.56 \%$ (oleic acid). Microbial analysis showed moderate standard plate counts (SPC) $3.0-4.0 \log (\mathrm{cfu} / \mathrm{g})$ and yeast and mould counts $1.0-2.3 \log (\mathrm{cfu} / \mathrm{g})$ in market samples of Mohanthal. Sensory attributes of highly preferred Mohanthal sample were: light brown to medium brown colour with rectangular shape, soft, cohesive and firm body with little crumbliness, small grains preferred over smooth texture, pleasant, nutty, roasted and caramelized flavor with rich ghee flavour. There is a need for further study to optimize a process for the preparation of Mohanthal so that dairy industry can produce this besan and milk solids based sweet on a large scale. This overall characterization of Mohanthal will also help in any further works to be taken up on Mohanthal for example cottage level manufacture, mechanization, setting of standards etc.
\end{abstract}

\footnotetext{
Dairy Technology Section,

ICAR- National Dairy Research Institute (Southern Regional Station), Adugodi, Bengaluru, India

MB Chaudhary $(\square)$

Dairy Technology Section,

ICAR- National Dairy Research Institute (Southern Regional Station), Adugodi, Bengaluru, India

Email: madhav.chaudhary5@gmail.com
}

Keywords: Mohanthal, Characterisation, Gujarat, Market survey, Traditional sweet, Composition, Textural characteristics

\section{Introduction}

India is a country known for its rich cultural heritage of various social and historical aspects including food and cuisines. It is a home to hundreds of varieties of sweetmeats on whose taste generations of people grew up. Many of traditional products find mention in oldest relics, which are popular even today (Pagote and Rao, 2012). Naturally, such sweet items have embedded in the psyche of the people here and continue to do so even in Indian diaspora abroad. But many of them could not withstand the onslaught of western products' publicity and became overshadowed so much so, that recent and present generations are blissfully unaware that so many varieties of sweets indeed existed in earlier years! It is only recently that the government realized the need to survey and document Indian traditional products, otherwise these products might be lost forever. Further, documentation of such products creates awareness among people in other parts of the country and may spur their commercial production as well. As such, Government of India lays emphasis on promoting indigenous technologies and encourages patent protection. It is in this direction that Indian Council of Agricultural Research has mandated Institutes to survey and characterize traditional Indian dairy products and National Dairy Research Institute is a part of such nationwide endeavour. This is possible by techniques like survey works, which were used by many workers earlier to characterize products like basundi, khoa, sweets etc. Such studies help to define the typical characteristics of products and will be of immense help in patenting processes. These results will serve as a base platform for the future works on the product. Also, the industry may think of manufacturing and marketing the traditional products because of their consumer appeal.

During our survey, we observed that traditional sweetmeats are basically prepared using three or four base materials such as milk, cereal flours, wheat/legumes particularly Bengal gram (Cicer arietinum) and fat. Using the above ingredients, the sweetmeat manufacturers are able to provide large variety of sweetmeats in 
the market place with their inherited art/skill and effective subtle changes in processing conditions. For example, the products like Laddu, Sohn papri, Mysore pak, Mohanthal and Besan burfi prepared using Bengal gram flour (besan) have similar ingredients, but the textures of these products are entirely different. Several of these region-specific traditional dairy products have been surveyed, characterized and documented. Mysore pak was launched by Karnataka Milk Federation and today it is one of the major revenue earners for the organization. In spite of such efforts, many products still remain unknown to other parts of the country. There is a need to document and preserve such traditional products. Several products have their origin in specific areas like Mysore pak (Mysore), Dharwad peda (Dharwad), Mathura peda (Mathura), kunda (Belgaum), basundi, khoa jalebi and shrikhand (Maharashtra), payasam (Karnataka and Kerala) etc. Mohanthal is one such region specific milk sweet.

Mohanthal is a traditional sweet product popular in Gujarat and some parts of Rajasthan. Mohan refers to 'Lord Krishna' and Thal refers to 'thali or plate'. Mohanthal is offered to Lord Krishna at various festivals. It is also a favourite at weddings. Mohanthal may be categorized under 'Cereal and pulses based dairy product'. Other Cereal and pulses based dairy products are: Mysore pak, doda burfi, pinni, kheer, payasam, halwasan etc. The history of Mohanthal origin is obscure and only a few scattered literatures are available related to Mohanthal. Traditionally Mohanthal is prepared at house hold levels and also by halwai's. It is observed on the basis of preliminary observations that the product Mohanthal is famous for its rich pleasant roasted flavor along with the rich ghee aroma. It is marketed in the form of small rectangular shaped pieces. The product showed wide variation from shop to shop. Mohanthal produced and marketed by local halwai's has a limited shelf life of 1-2 weeks.

\section{Materials and Methods}

\section{Procurement of Mohanthal samples}

Mohanthal is prepared in many households in Gujarat. It is also being sold in various sweet shop outlets in towns and cities. Based on survey work, and through various sources and media, well known manufacturers of Mohanthal were identified for the study. In all sixteen samples of Mohanthal were procured from selected cities namely Ahmedabad (C-1), Anand (C-2), Vadodara (C-3) and Palanpur (C-4). Four samples of Moahnthal from reputed manufacturers from each city were collected. As good number of product manufacturing units was present in these cities, they were able to meet local market demand as well as supply the product to nearby regions too. A few selected samples from well-known manufacturers were brought to Southern Regional Station of ICAR-NDRI in their packaging containers and evaluated for sensory, textural, microbial and physicochemical parameters.

\section{Sensory evaluation}

Sensory evaluation of the procured Mohanthal samples was carried out by semi-trained faculty of Dairy Technology Section of the institute using 9-point hedonic scale and descriptive sensory evaluation technique, in hygienic and well ventilated laboratory. The judges were asked to evaluate and describe various product attributes viz. colour and appearance, flavour, body and texture, sweetness and overall acceptability.

\section{Analytical}

\section{Texture profile}

Texture profile analysis of the samples of Mohanthal was carried out using Texture Analyzer, TA-XT plus Stable Micro System, England (Bourne, 1975). The instrumental test protocols maintained were: Option: return to start; Test mode : compression; Pre-test speed: $1 \mathrm{~mm} / \mathrm{s}$; Test speed : $5 \mathrm{~mm} / \mathrm{s}$; Post-test speed: 5 $\mathrm{mm} / \mathrm{s}$; Target mode : Distance; Distance: $10 \mathrm{~mm}$; Time : $5 \mathrm{sec}$; Trigger type: Auto (Force); Trigger force : 5 g; Break Mode : Off; Advanced option: ON; Probe: $\mathrm{P} / 75$ plunger probe

Mohanthal sample, gently patted into cubes of $20 \times 20 \times 20 \mathrm{~mm}$ and tempered at $30^{\circ} \mathrm{C}$ for about an hour, was kept positioned centrally over the platform of Texture Analyser and the computer was allowed to execute the program to run the test, then the sample was compressed ( $50 \%$ compression) by the plunger twice (resembling two bites) and the force exerted back by the sample onto the plunger was sensed by the machine generating a two peak force - time curve. Different textural parameters like hardness (Newtons), cohesiveness (no units), spinginess (no units), gumminess (Newtons), and chewiness (Newtons) were computed from the force-time graph as described by Patel and Rao (2013).

\section{Proximate composition}

The market samples of Mohanthal were thoroughly mixed using pestle and mortar and the homogeneous mass was used for all the analyses. The nuts embedded on the surface as well as silver coating, if any were carefully removed before grinding. The following physico-chemical estimations were made by the methods mentioned: moisture content-gravimetric method (BIS, 1981), fat content-Mojonnier method (AOAC, 2005), ash content - gravimetric method (AOAC, 2005), total protein - Kjeldahl method (AOAC, 2005), lactose and sucrose - volumetric method (BIS, 1981), and other carbohydrates- by difference, FFA - Thomas et al. (1954).

\section{Colour}

The properly mixed sample of Mohanthal was stuffed into scratchless petriplate (Diameter: $3 \mathrm{~cm}$ ) and the bottom surface exposed to scanner (Hewlett-Packard Scan jet 5370c). The scanned image was opened in Adobe Photoshop and colour parameters 
measured as described by and Vyawahare and Rao (2011). Browning Index (BI), Yellowness Index (YI) and Whiteness Index (WI) were computed as described by Yam and Papadakis (2004).

\section{Microbiological}

All the market samples of Mohanthal were analyzed for standard plate count (SPC) and yeast and mould count by BIS (1981) method (pour plate method).

\section{Statistical}

The data of various attributes of sixteen Mohanthal samples from different markets were statistically analyzed employing one way ANOVA along with Tukey test using SPSS software, to know the variations in samples between markets.

\section{Results and Discussion}

The market samples collected from different cities are shown in Fig. 1 and their sensory descriptions are given in Table 1. It may be seen that many samples are mixed and garnished with nuts. Natural colour of Mohanthal was observed to be light to medium brown, however, added colour and silver foil coatings are adopted by some manufacturers for consumer appeal. As a traditional practice as well as for typical body and textural attribute, Mohanthal is always sold in rectangular or cubical shaped.

\section{Chemical composition of Mohanthal}

The fat content of Mohanthal collected from different markets varied from $18.21-28.12 \%$ (Table 2 ), with an average for all markets of $23.74 \%$, and statistical analysis indicated a significant variation between the markets. All other constituents also varied significantly $(\mathrm{P}<0.05)$, the protein content ranging from $8.27-$ 13.00 , lactose $0.00-12.10$, sucrose $19.00-29.56$, moisture $8.64-$ 13.86 and ash $0.81-1.81, \%$ respectively. These variations in the samples from market to market could be attributed to the following reasons: 1) halwais use besan of different ages; as per halwais, fresh besan gives different texture and taste than stored one 2) use of milk solids other than skim milk powder and khoa 3) extent of roasting is arbitrary and manually controlled depending on the time availability and personal preferences; 4) sugar syrup concentration varies, because sugar and water are not weighed properly and used in arbitrary quantities. It is also boiled for

Table 1 Descriptive sensory characteristics of market samples of Mohanthal collected from different markets

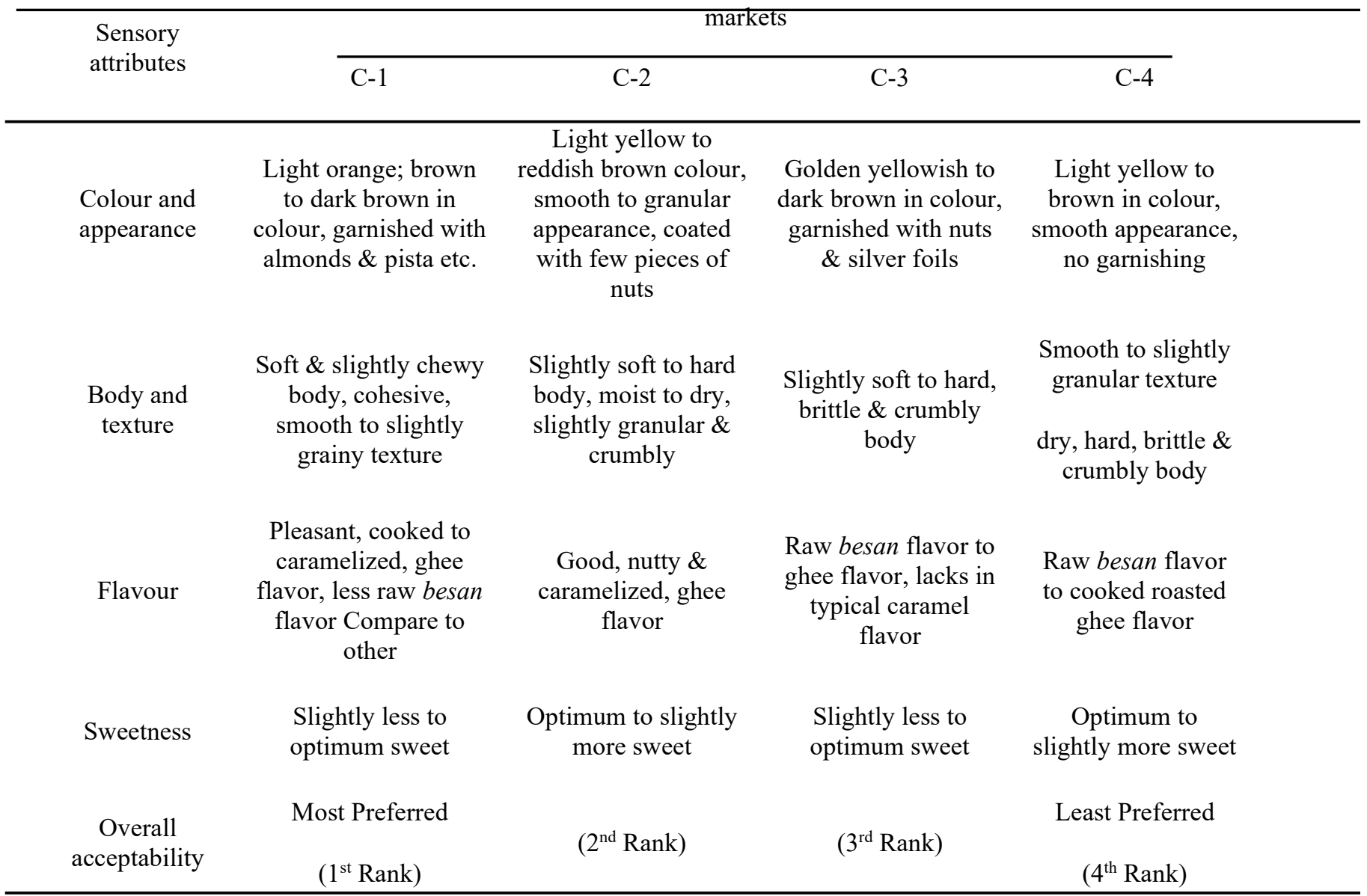


Fig. 1 Market Samples of Mohanthal from different cities of Gujarat
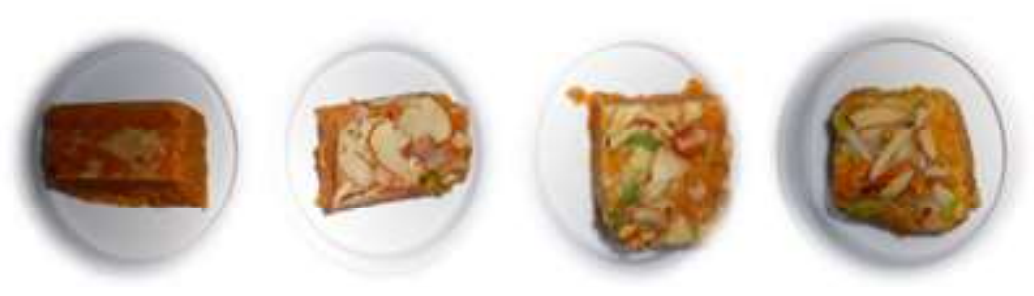

A. Market Samples of Mohanthal fr om Ahmed abad City
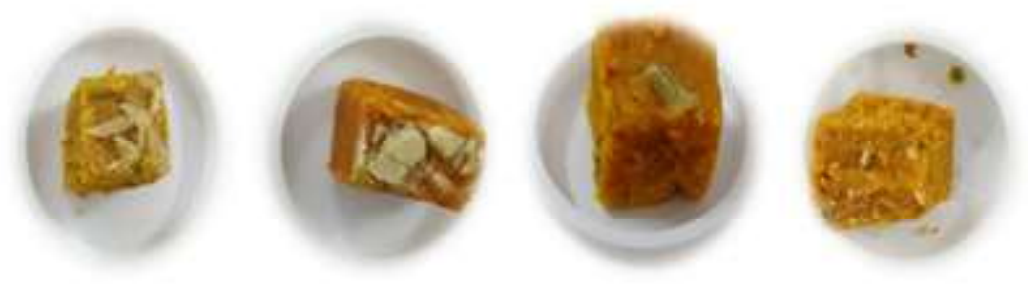

B. Market Samples of Mohanthal from Anand City
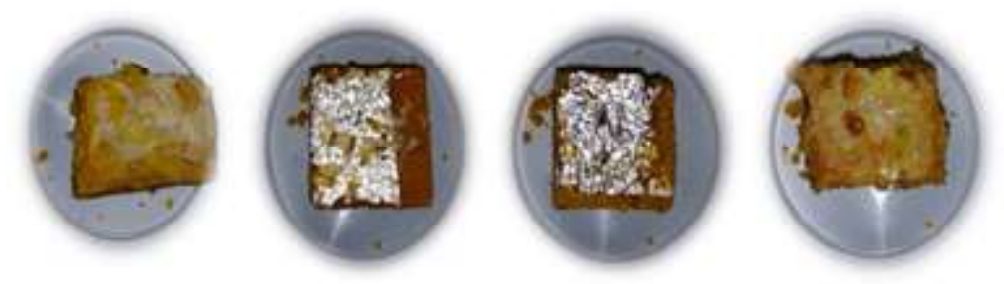

C.Market Samples of Mohanthal from Vadodarn City
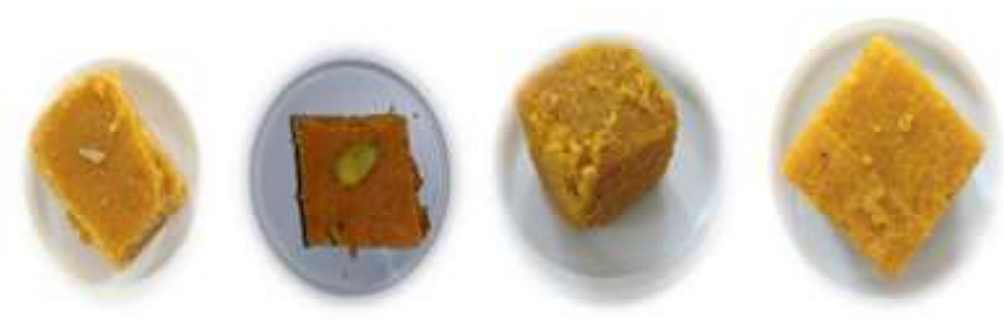

D. Market Samples of Mohanthal fr on Pahnpur City

such times as per convenience and 5) Use of other optional ingredients like nuts.

The variation in the moisture content of Mohanthal among manufacturers within a particular city may be due to the difference in their manufacturing techniques, sugar syrup concentration and the marketing requirements. The lower or higher moisture content may also be responsible for its higher or lower storage life. The fat content obtained in Mohanthal was comparable to the fat content found in the various other heat desiccated dairy products such as peda (Patel and Gandhi 1980; Vijayakhader and Patel 1983; Miyani 1988; Patel 1996; Ray et al. 2002), burfi (Rastogi et al. 1966; Miyani et al.1982; Garg and Mandokhot 1987), kalakand (Moulick et al. 1996), kunda (Kulkarni et al. 2001) and milk cake
(Madhava Rao et al. 2003; Kumar et al. 2016) the values ranging from 3.3-28.54 \%. During analysis of market samples of Mohanthal for lactose, it was found that some of the samples did not contain any lactose or had in it in very minor level which was not easily detectable. This may be due to the reason that milk or khoa was not used in those samples because milk solids are the only source of lactose in nature (Nickerson, 1974). But in a few samples, lactose was found very high, around $12.10 \%$, which indicates that skim milk powder may have been used. The 'other carbohydrates' content of Mohanthal mainly comes from bengal gram flour (besan), which is one of the major ingredients of Mohanthal. Free fatty acids (FFA) are the measure of the fatty acids liberated from the triglycerides due to fat degradation occurring in the product prior to or after manufacturing. It is responsible for the 
Table 2 Chemical composition* of Mohanthal collected from different markets

\begin{tabular}{|c|c|c|c|c|c|c|}
\hline \multirow[t]{2}{*}{ Constituent } & \multicolumn{4}{|c|}{ Markets } & \multirow[b]{2}{*}{$\begin{array}{l}\text { Range for all } \\
\text { markets, } n=16\end{array}$} & \multirow{2}{*}{$\begin{array}{l}\text { Average of } \\
\text { all markets }\end{array}$} \\
\hline & $\overline{\mathrm{C}-1}$ & $\mathrm{C}-2$ & C-3 & $\mathrm{C}-4$ & & \\
\hline Moisture (\%) & $12.22 \pm 0.98^{\mathrm{d}}$ & $9.98 \pm 0.80^{\mathrm{b}}$ & $10.99 \pm 0.54^{\mathrm{c}}$ & $9.25 \pm 0.51^{\mathrm{a}}$ & $8.64-13.86$ & $10.61 \pm 1.33$ \\
\hline Protein $(\%)$ & $9.53 \pm 1.72^{\mathrm{ab}}$ & $10.47 \pm 1.15^{\mathrm{bc}}$ & $9.21 \pm 0.82^{\mathrm{a}}$ & $11.02 \pm 1.33^{\mathrm{c}}$ & $8.27-13.00$ & $10.05 \pm 1.47$ \\
\hline Sugar $(\%)$ & $22.13 \pm 2.27^{\mathrm{a}}$ & $26.35 \pm 2.27^{\mathrm{c}}$ & $24.41 \pm 2.09^{\mathrm{b}}$ & $27.62 \pm 1.33^{\mathrm{c}}$ & $19.00-29.56$ & $25.13 \pm 2.89$ \\
\hline Other & $27.85 \pm 2.80^{\mathrm{a}}$ & $27.11 \pm 3.76^{\mathrm{a}}$ & $27.44 \pm 4.69^{\mathrm{a}}$ & $24.41 \pm 6.78^{a}$ & $17.61-32.95$ & $26.69 \pm 4.85$ \\
\hline \multicolumn{7}{|l|}{ Carbohydrates (\%) } \\
\hline FFA $(\%$ oleic acid $)$ & $1.14 \pm 0.22^{\mathrm{ab}}$ & $1.09 \pm 0.07^{\mathrm{a}}$ & $1.27 \pm 0.19^{\mathrm{b}}$ & $1.13 \pm 0.20^{\mathrm{ab}}$ & $0.85-1.56$ & $1.16 \pm 0.18$ \\
\hline $\mathrm{pH}$ & $6.47 \pm 0.04^{\mathrm{b}}$ & $6.42 \pm 0.04^{\mathrm{ab}}$ & $6.38 \pm 0.10^{\mathrm{a}}$ & $6.39 \pm 0.10^{\mathrm{a}}$ & $6.25-6.53$ & $6.41 \pm 0.08$ \\
\hline
\end{tabular}

Values in a row with different superscripts are significantly different between markets (cities) at $\mathrm{p} \leq 0.05, *$ mean values \pm SE, $\mathrm{n}=4$

Table 3 Textural characteristics* of Mohanthal collected from different markets

\begin{tabular}{|c|c|c|c|c|c|c|}
\hline \multirow{2}{*}{$\begin{array}{l}\text { Textural } \\
\text { Characteristics }\end{array}$} & \multicolumn{5}{|c|}{ Markets } & \multirow{2}{*}{$\begin{array}{l}\text { Average of } \\
\text { all markets }\end{array}$} \\
\hline & $\overline{\mathrm{C}-1}$ & $\mathrm{C}-2$ & $\mathrm{C}-3$ & $\mathrm{C}-4$ & $\begin{array}{l}\text { Range for all } \\
\text { markets, } n=16\end{array}$ & \\
\hline$\overline{\text { Hardness }(\mathrm{N})}$ & $4.64 \pm 0.56^{\mathrm{a}}$ & $10.40 \pm 1.84^{\mathrm{b}}$ & $9.17 \pm 1.25^{\mathrm{b}}$ & $14.63 \pm 3.49^{c}$ & $3.44-20.24$ & $9.71 \pm 4.18$ \\
\hline Cohesiveness & $0.132 \pm 0.020^{\mathrm{b}}$ & $0.071 \pm 0.014^{\mathrm{a}}$ & $0.140 \pm 0.022^{\mathrm{b}}$ & $0.077 \pm 0.008^{\mathrm{a}}$ & $0.051-0.178$ & $0.105 \pm 0.035$ \\
\hline Springiness & $0.203 \pm 0.021^{\mathrm{a}}$ & $0.225 \pm 0.015^{\mathrm{b}}$ & $0.200 \pm 0.017^{\mathrm{a}}$ & $0.197 \pm 0.031^{\mathrm{a}}$ & $0.158-0.265$ & $0.206 \pm 0.020$ \\
\hline Gumminess (N) & $0.610 \pm 0.095^{\mathrm{a}}$ & $0.720 \pm 0.105^{\mathrm{a}}$ & $1.274 \pm 0.184^{\mathrm{b}}$ & $1.127 \pm 0.318^{\mathrm{b}}$ & $0.464-1.562$ & $0.932 \pm 0.328$ \\
\hline
\end{tabular}

Values in a row with different superscripts are significantly different between markets (cities) at $p \leq 0.05$

*mean values $\pm \mathrm{SE}, \mathrm{n}=4$

development of rancidity during storage. The $\mathrm{pH}$ of all the market samples ranged from 6.25 to 6.53 . The highest $\mathrm{pH}$ was found in C-1 market samples, which was significantly $(\mathrm{p} \leq 0.05)$ higher than $\mathrm{C}-3$ and $\mathrm{C}-4$ market samples. There was significant $(\mathrm{p} \leq 0.05)$ difference found among samples from same market (Table 2).

\section{Textural characteristics of Mohanthal}

The instrumental textural attributes varied widely depending on the market as well as the manufacturer. Hardness of Mohanthal varied from $3.44-20.24 \mathrm{~N}$ and cohesiveness from $0.051-0.178$ (Table 3). The variations in the textural attributes are indicated by standard error values. The least hardness was observed in C1 (Ahmedabad samples) $(4.64 \mathrm{~N})$ and the highest in C-4 (Palanpur samples) $(14.63 \mathrm{~N})$. It was noticed that cohesiveness, springiness, gumminess and chewiness values were much less than those of other similar dairy products (Chawla et al. 2011). This can be attributed to the presence of roasted besan particles. Raw besan particles have a very good water binding ability and strength, but on roasting, they lose the water binding, hence impart typical brittleness desirable to Mohanthal coupled with presence of sugar (Wani and Kumar, 2014). The variation in hardness may be ascribed to the variation in moisture, fat and total sugar content of the samples. Samples of C-1 city contained maximum amount of moisture and maximum amount of fat amongst others and could probably be correlated with minimum hardness. During TPA testing procedure, after first bite of TPA, Mohanthal lost its original shape and texture and became little bit floury, which shows brittle nature of the product and lower cohesiveness value in C-2 and C-4 samples.

\section{Sensory and physico-chemical characteristics of Mohanthal}

Mohanthal is generally rectangular or cubical in shape with a thickness of about 2.0-3.0 cm. It resembles 'coloured' burfi sold in the market, but with a higher thickness. The colour is light brown to medium brown. This of course depends on the extent and uniformity of roasting during manufacture. When cut, it could be found that the interior of the pieces was uniformly brown. The colour was measured instrumentally in terms of Browning Index (BI), Yellowness Index (YI) and Whiteness Index (WI) all of which are related inversely with each other. Higher BI values indicated more brown colour caused by roasting of besan during manufacture and resulted in lower WI values. However, YI values have more to do with added colour. Further, added colour might decrease WI values. But, interestingly consumers still like added colours because of more visual appeal. The body of Mohanthal is firm, but slightly brittle, crumbling when pressed hard. However, because of roasted besan, the body is grainy thus imparting chewiness in mouth. The taste of Mohanthal is pleasantly sweet, slightly caramelized and has typical roasted besan flavour. There 
was not much variation in the flavor of Mohanthal collected from different markets, but those brought from C-1 (Ahmedabad) had better quality.

Thus, the sensory attributes of Mohanthal were found to be typical of the product and had profound effect on the consumers'preference. These attributes are the result of compositional constituents and the processing methodology employed during manufacturing. All the market samples were more or less well accepted by judges, but some samples were more acceptable than others because of typical Mohanthal characteristics. The average colour and appearance, flavour, body and texture, sweetness and overall acceptance scores were: $8.01 \pm 0.31,7.81 \pm 0.44,7.75 \pm 0.31,8.13 \pm 0.14$ and $7.84 \pm 0.31$, respectively. All the colour and appearance values for the samples collected from different cities showed significant $(p \leq 0.05)$ difference between cities (Table 2).

The wide range in values of colour and appearance score of samples collected from each city clearly revealed manufacturer to manufacturer variation. This may be due to lack of proper care during preparation, wide variations in ingredients, use of different type of garnishing and colouring materials and also poor packaging materials. In the present study, some of the observations were also described by sensory judges which included light yellow orange to dark brown colour, smooth to granular appearance and no garnishing to well garnished with nuts and silver foil coat (Table 1). Similar variations were reported by Patel (1996) for market peda and Londhe (2006) for brown peda and Anon. (2006) for kunda. The variation in colour and appearance score of samples collected from each city was also attributed to level of ghee, sugar addition and moisture content of the product.

The wide range in values of body and texture score of samples collected from each city could be mainly ascribed to variation in moisture and fat contents. In the present study, judges described Mohanthal as having moist and soft to hard and dry, cohesive to brittle and crumbly body with small to medium grains and granular texture. All the flavor scores obtained for the samples collected from different cities showed significant $(p \leq 0.05)$ difference (Table 5). The highest and lowest mean scores 8.35 and 7.46 were obtained from $\mathrm{C}-1$ and $\mathrm{C}-4$ cities, which were significantly $(\mathrm{p} \leq 0.05)$ different from other three cities, while mean score of C-2 and C-3 didn't show any difference. The wide range in values of flavour score of samples collected from each city clearly revealed shop to shop variation. This may be due to variation in preparation method and composition of the ingredients, particularly, besan, ghee and sugar levels in the final product. In the present study, some of the observations were also described by sensory judges, which included pleasant roasted ghee with caramelized and nutty flavour with added

Table 4 Colour parameters* of Mohanthal collected from different markets

\begin{tabular}{|c|c|c|c|c|c|c|}
\hline$\overline{\text { Colour }}$ & & Markets & & & & Average of \\
\hline Parameters & $\bar{C}-1$ & $\mathrm{C}-2$ & $\mathrm{C}-3$ & $\mathrm{C}-4$ & $\begin{array}{l}\text { Range } \\
\text { for all markets, } n=16\end{array}$ & all markets \\
\hline $\begin{array}{l}\text { Browning } \\
\text { Index }\end{array}$ & $186.82 \pm 6.60^{\mathrm{ab}}$ & $185.54 \pm 30.51^{\mathrm{ab}}$ & $189.81 \pm 9.47^{\mathrm{b}}$ & $169.66 \pm 26.85^{\mathrm{a}}$ & $140.00-222.00$ & $182.96 \pm 22.40$ \\
\hline $\begin{array}{l}\text { Yellowness } \\
\text { Index }\end{array}$ & $126.95 \pm 5.05^{\mathrm{b}}$ & $126.41 \pm 12.38^{b}$ & $125.43 \pm 3.48^{\mathrm{ab}}$ & $118.74 \pm 10.43^{\mathrm{a}}$ & $107.00-139.60$ & $124.38 \pm 9.21$ \\
\hline $\begin{array}{l}\text { Whiteness } \\
\text { Index }\end{array}$ & $30.58 \pm 1.12^{\mathrm{ab}}$ & $31.47 \pm 3.72^{\mathrm{ab}}$ & $29.66 \pm 1.83^{\mathrm{a}}$ & $32.89 \pm 4.09^{\mathrm{b}}$ & $27.00-37.33$ & $31.15 \pm 3.17$ \\
\hline
\end{tabular}

Values in a row with different superscripts are significantly different between markets (cities) at $p \leq 0.05$; Colour parameters measured by computer vision *mean values $\pm \mathrm{SE}, \mathrm{n}=4$

Table 5 Sensory acceptance scores* of Mohanthal collected from different markets

\begin{tabular}{lllllll}
\hline Sensory attributes & \multicolumn{3}{c}{ Markets } & & $\begin{array}{l}\text { Range for } \\
\text { all markets, } \mathrm{n}=16\end{array}$ & $\begin{array}{l}\text { Average of } \\
\text { all markets }\end{array}$ \\
\cline { 2 - 4 } & $\mathrm{C}-1$ & $\mathrm{C}-2$ & $\mathrm{C}-3$ & $\mathrm{C}-4$ & & $8.01 \pm 0.31$ \\
\hline $\begin{array}{l}\text { Colour and } \\
\text { appearance }\end{array}$ & $8.34 \pm 0.30^{\mathrm{c}}$ & $8.06 \pm 0.42^{\mathrm{b}}$ & $7.95 \pm 0.42^{\mathrm{b}}$ & $7.69 \pm 0.47^{\mathrm{a}}$ & $6.75-8.75$ & \\
Body and texture & $8.08 \pm 0.23^{\mathrm{b}}$ & $7.69 \pm 0.42^{\mathrm{a}}$ & $7.74 \pm 0.25^{\mathrm{a}}$ & $7.60 \pm 0.36^{\mathrm{a}}$ & $6.75-8.50$ & $7.75 \pm 0.31$ \\
Flavour & $8.35 \pm 0.30^{\mathrm{c}}$ & $7.72 \pm 0.39^{\mathrm{b}}$ & $7.73 \pm 0.29^{\mathrm{b}}$ & $7.46 \pm 0.42^{\mathrm{a}}$ & $6.75-9.00$ & $7.81 \pm 0.44$ \\
Sweetness & $8.17 \pm 0.20^{\mathrm{b}}$ & $7.99 \pm 0.27^{\mathrm{a}}$ & $8.23 \pm 0.21^{\mathrm{b}}$ & $8.13 \pm 0.29^{\mathrm{ab}}$ & $7.75-8.50$ & $8.13 \pm 0.14$ \\
$\begin{array}{l}\text { Overall } \\
\text { acceptability }\end{array}$ & $8.19 \pm 0.18^{\mathrm{c}}$ & $7.80 \pm 0.25^{\mathrm{b}}$ & $7.83 \pm 0.33^{\mathrm{b}}$ & $7.54 \pm 0.32^{\mathrm{a}}$ & $6.75-8.50$ & $7.84 \pm 0.31$ \\
\hline
\end{tabular}

Values in a row with different superscripts are significantly different between markets (cities) at $p \leq 0.05$

*mean values $\pm \mathrm{SE}$; maximum, $9.0, \mathrm{n}=4$ 
Fig.2 Flow chart of manufacture method of Mohanthal

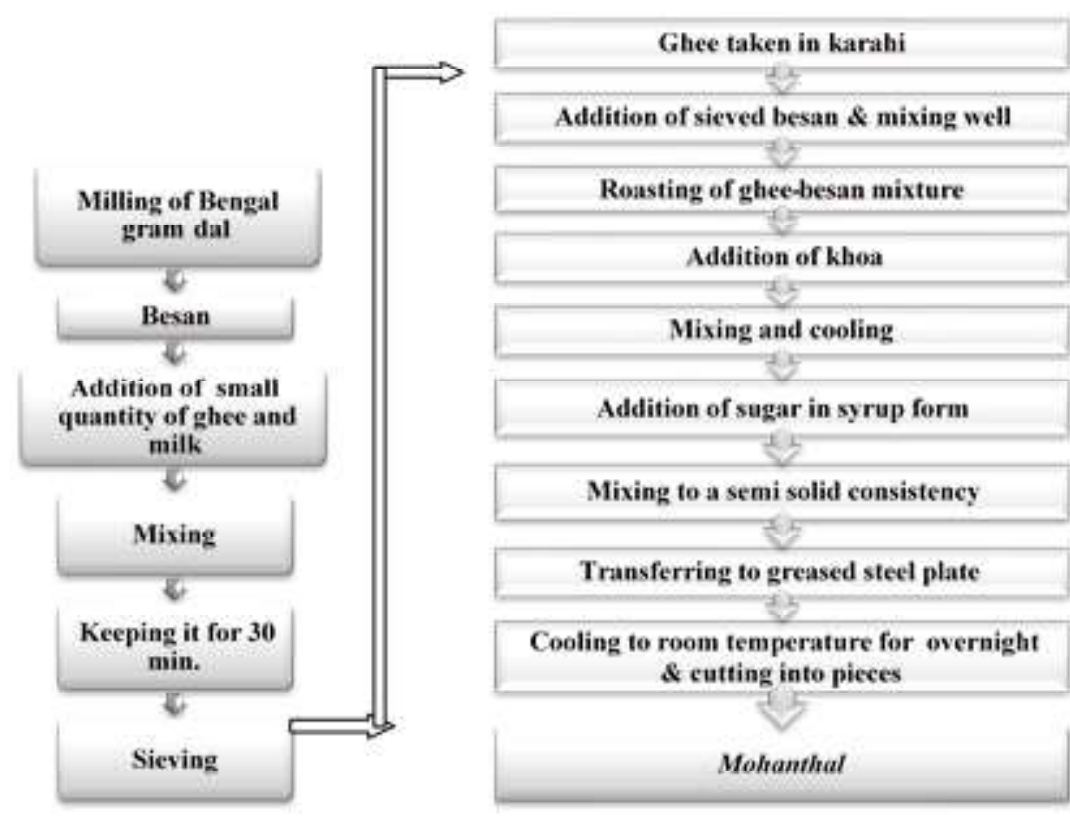

Table 6 Microbiological counts* of market samples of Mohanthal collected from different cities of Gujarat

\begin{tabular}{|c|c|c|c|c|c|c|}
\hline \multirow{2}{*}{$\begin{array}{l}\text { Microbial Count } \\
\log (\mathrm{cfu} / \mathrm{g})\end{array}$} & \multicolumn{4}{|c|}{ Markets } & \multirow{2}{*}{$\begin{array}{l}\text { Range for } \\
\text { all markets, } n=16\end{array}$} & \multirow{2}{*}{$\begin{array}{l}\text { Average of } \\
\text { all markets }\end{array}$} \\
\hline & $\overline{\mathrm{C}-1}$ & $\mathrm{C}-2$ & $\mathrm{C}-3$ & C-4 & & \\
\hline Standard Plate Count & $3.75 \pm 0.18^{\mathrm{a}}$ & $3.72 \pm 0.10^{\mathrm{a}}$ & $3.72 \pm 0.33^{\mathrm{a}}$ & $3.96 \pm 0.04^{\mathrm{b}}$ & $3.00-4.00$ & $3.79 \pm 0.21$ \\
\hline Yeast and Mould Count & $1.83 \pm 0.11^{\mathrm{a}}$ & $1.96 \pm 0.21^{\mathrm{a}}$ & $1.86 \pm 0.39^{\mathrm{a}}$ & $1.96 \pm 0.22^{\mathrm{a}}$ & $1.00-2.30$ & $1.90 \pm 0.18$ \\
\hline
\end{tabular}

Values in a row with different superscripts are significantly different between markets (cities) at $\mathrm{p} \leq 0.05, *$ mean values $\pm \mathrm{SE}, \mathrm{n}=4$

cardamom. In some samples, raw besan flavor was also observed which was liked least. From overall acceptability scores, it was clearly revealed that city $\mathrm{C}$ - 1 samples were better in comparison to other 3 cities in sensory attributes.

\section{Ideal characteristics of Mohanthal}

Sensory attributes of highly preferred Mohanthal sample include light brown to medium brown colour, soft bodied but enough firmer and cohesive to cut in rectangular pieces, holding its shape without becoming floury, and small besan grains preferred over smooth texture. It must have pleasant, nutty, roasted and caramelized flavor with ghee flavour but raw besan flavour is not preferable. Garnishing with nuts such as almonds and pistachio or addition of saffron, cardamom or nutmegs enhances visual appearance and flavour of product, respectively.

\section{Microbiological quality of Mohanthal}

All the food products sold in market contain microbes, because microorganisms enter the product at various stages during the processing and manufacture, and through packages from environment, if not packed properly. However, the number of microorganisms depends on the moisture content of the product, because at low water contents, they multiply slowly. In case of
Mohanthal, moisture is low and sugar content is high, so we expect lower counts than other dairy products. The average values for SPC of Mohanthal samples collected from C-1, C-2, C-3 and C-4 markets were 3.75, 3.72, 3.72 and $3.96 \log (\mathrm{cfu} / \mathrm{g})$, respectively. The highest SPC was found in C-4 (Palanpur). In general, there was significant $(\mathrm{p} \leq 0.05)$ difference found among samples from the same market (Table 6). Wide variations in SPC counts of market samples of plain peda were reported by earlier workers. Ghodekar et al. (1974), Kamat and Sulebele (1974), Dwarkanath and Srikanta (1977) and Garg and Mandokhot (1987) reported $2 \times 10^{3}-3 \times 10^{5}, 6 \times 10^{2}-1 \times 10^{7}, 7.6 \times 10^{2}-5 \times 10^{3}$ and $1.1 \times 10^{3}-5.6 \times 10^{3}$ per gm, respectively. The average values for yeast and mould count of Mohanthal samples collected from C-1, C-2, C-3 and C-4 markets were $1.83 \pm 0.11,1.96 \pm 0.21,1.86 \pm 0.39$ and $1.96 \pm 0.22 \log (\mathrm{cfu} / \mathrm{g})$, respectively and the range was from $1.60-2.00,1.60-2.30,1.00$ 2.30 and $1.48-2.26 \log (\mathrm{cfu} / \mathrm{g})$, respectively. There was no significant $(\mathrm{p}>0.05)$ difference in the samples found among the cities (Table 6). However, there was variation found in yeast and mould counts in samples collected from each market. Similar findings have been reported in khoa by Singh et al. (1975) in Mysore pak and kalakand by Dwarkanath and Srikanta (1977) and in burfi by Garg and Mandokhot (1984). Lower SPC and yeast and mould counts were found in all the samples of Mohanthal when compared to other traditional dairy products, which may be due to high roasting temperature employed during 
Mohanthal preparation as well as low moisture of the product. The SPC and yeast and mould counts found in samples may be due to post processing contamination; unhygienic practices followed by manufacturers, using inappropriate packaging materials and long duration kept between manufacturing and packaging of product.

\section{Ingredients and manufacturing aspects}

Based on the survey work, the most common ingredients used for manufacture of Mohanthal were found to be besan, sugar, ghee and khoa. The critical factor agreed up on by all the halwais is the extent of roasting of besan during manufacture. Besan contains major constituents (17-22\%) protein and (50\%) carbohydrate (Saleh and Tarek, 2006). Roasting of besan releases compounds which provide relishing flavour, however more roasting results in charring of proteins and carbohydrates which may cause slight bitterness (Hodge et al. 1972). However, their proportions varied depending on the manufacturer. The method of preparation is shown in Fig. 2. The ingredients are mixed well till the mixture attains a bread crumb consistency. After proper mixing, the mixture is kept undisturbed for half an hour. This mixture is named dhrabo. Ghee is taken in a separate vessel and heated till it melts completely. Then dhrabo is added to the molten ghee and heated till the mixture develops a light brown colour and pleasant roasted flavor. The ghee besan mixture is then allowed to cool for some time. Sugar syrup (one thread consistency) is added to the prepared mixture and continuous mixing is done till it attains a semi solid form. Finally, the product is spread on a greased dish and garnished with nuts and cardamom. The product is then allowed to cool by keeping it overnight. Next day, the product is cut into pieces and served.

\section{Conclusions}

Mohanthal is a versatile traditional product of Gujarat state with sensory characteristics of its own. Use of pulse flour (besan) imparts its typical colour and flavor. The study of market samples of Mohanthal showed variations in its quality characteristics and quality of best Mohanthal has been described. Presence of SPC, yeast and mold counts in market samples indicated the lack of proper hygienic practices adopted for preparation and handling of the product. Results obtained during the present investigation are of great importance in determination of product quality. To add a new item in the food basket of the global consumers with uniform quality and improved safety, large scale production and marketing of this product can be taken up by organized sector. Consequently, optimization of process parameters will act as a pre-requisite to showcase this product as a typical Indian traditional product in various forums. Based on the results, industry can manufacture Mohanthal for commercial activity and popularize the product throughout the country for the benefit of consumers.

\section{Acknowledgements}

The Senior Fellowship of NDRI (Deemed University) granted to the first author is gratefully acknowledged.

\section{References}

Adhikari AK, Mathur ON, Patil GR (1994) Interrelationships among Instron textural parameters, composition and microstructure of khoa and gulabjamun made from buffalo milk. J Food Sci Technol 31: 279-284.

Anon. (2006) Research and development support for process up-gradation of indigenous milk products for industrial application. Network Project Report, NDRI (Southern Campus), Bangalore.

AOAC (2005) Official methods of analysis of AOAC international, $18^{\text {th }}$ Ed., Washington D.C.

BIS. IS: SP: 18 ISI (1981) Handbook of food analysis. (Part XI). Dairy products. Indian Standard Institution, Manak Bhavan, New Delhi

Chawla R, Patil GR, Singh AK (2011) Physicochemical and textural attributes of market sample of Doda burfi. Dairy Foods Int 1: 176183

Dwarkanath CT, Srikanta, S (1977) Studies on the microbiological quality of traditional Indian sweet meat products. J Food Sci Technol 14: 201-204

Garg SR, Mandokhot UV (1984) Studies on microbial and chemical profile of some Indian sweet meats and their significance. Indian J Dairy Sci 37: 326-333.

Garg SR, Mandokhot UV (1987) Survival and growth of microorganisms in burfi and peda during storage. Indian J Dairy Sci 40: 119-121

Ghodekar DR, Dudani AT, Ranganadham B (1974) Microbiological quality of Indian milk products. J Milk Food Technol 31: 119-122

Gupta SK, Patil GR, Patel AA, Garg FC, Rajorhia GS (1990) Instron texture profile parameters of khoa as influenced by composition. J Food Sci Technol 27: 209-213

Hemavathy J, Prabhakar JV (1973) Changes in the carbonyl composition of a milk based sweetmeat-burfi during preparation and storage. $\mathrm{J}$ Food Sci Technol 10: 156-160

Hodge JE, Mills FD, Fisher BE (1972) Compounds of browned flavor derived from sugar-amine reactions. Am Assoc Cereal Chem 17: $34-$ 40

Jailkhani VK, De S (1979) Utilization of goat milk for khoa making. Indian J Dairy Sci 33:29-33.

Kamat MY, Sulebele GA (1974) Microbiological quality of peda. J Food Sci Technol 11: 50-53

Kulkarni S, Ghosh BC, Balasubramanyam BV, Rao KJ (2001) Kundadesiccated dairy product of northern Karnataka. Indian Dairyman 53: 65-68

Kumar A, Patil GR, Singh RRB, Gupta H, Kandpal S, Shahi N (2016) A comparative study on the quality of laboratory-made and market samples of milkcake-a traditional Indian sweet. J Hill Agric 7: 139

Londhe GK (2006) Development of a process for manufacture and shelf life extension of brown peda. Ph.D. Thesis submitted to National Dairy Research Institute, Deemed Univ. Karnal, India.

Madhava Rao T, Reddy CR, Ranganadham M, Laxminarayana M (2003) Standardization of the method for milk cake preparation. Indian J Dairy Sci 56: 397-399

Miyani RV (1988) Evaluation of influence of various processing parameters on the rheological properties of khoa and penda, Ph.D. Thesis submitted to Gujarat Agricultural University, Gujarat.

Miyani RV, Vyas SH, Upadhyay KG, Thakar PN (1982) Effect of different fat levels of cow and buffalo milk on the acceptability and shelf-life of penda. GAU Res J 8: 45-48 
Moulick S, Ghatak P, Bandyopadhyay AK (1996) A comparative study on the quality of market and laboratory-made kalakand. Indian J Dairy Sci 49: 406-412

Nickerson TA (1974) Lactose, In Fundamentals of Dairy Chemistry (eds B.H. Webb, A.H. Johnson and J.A. Alford), AVI Publishing, Westport, CT, 273-324

Patel HA (1996) Comparative appraisal of quality of peda manufactured and sold in selected cities of Gujarat state, M.Sc. Thesis submitted to Gujarat Agricultural University, Gujarat

Patel MM, Gandhi NN (1980) Analysis of Gopal peda, XVI Dairy Industry Conference, Pune

Pati, G., Patel AA, Garg FC, Rajorhia GS, Gupta SK (1990) Interrelationship between sensory and instrumental data on texture of khoa. J Food Sci Technol 27: 167-170

Rao RS, Goyal GK (2007) Effect of packaging and storage on the sensory quality of kalakand. Indian J Dairy Sci 60: 77-88

Rastogi MK, Verma IS, Paul IJ (1966) XVII International Dairy Congress., E/F. 273-278. Cited from: Reddy CR, and Rajorhia GS (1992) Present status of peda and burfi technology - review. Indian J Dairy Sci 45: 220-225

Ray PR, Bandyopadhyay AK, Ghatak PK (2002) Comparative studies on quality of market available and laboratory made peda. Indian J Dairy Sci 55: 83-85

Sachdeva S, Rajorhia GS (1982) Studies on the technology and shelf life of burfi. Indian J Dairy Sci 35: 513-516

Saleh AA, Tarek AE (2006) Nutritional composition of chickpea (Cicer arietinum $\mathrm{L}$.) as affected by microwave cooking and other traditional cooking methods. J Food Comp Anal 19: 806-812
Saxena AK, Kulkarni SG, Berry SK, Sehgal RC, Beerh OP (1996) Preparation, packaging and storage of pinni: an Indian traditional sweet. J Food Sci Technol 33: 503-505

Sharma UP, Zariwala IT (1978) Survey of quality of milk products in Bombay. J Food Sci Technol 15: 118-121

Singh K, Ogra JL, Rao YS (1975) Observations on the microbiological quantity of some indigenous concentrated milk products. Indian $\mathrm{J}$ Dairy Sci 28: 304-305

Suresh I, Jha YK (1994) Sensory, biochemical and microbiological qualities of kalakand. J Food Sci Technol 31: 330-332

Thomas WR, Harper WJ, Fould IA (1954) Free fatty acid content of fresh milk as related to proteins of milk drawn. J Dairy Sci 37: 717-719

Vijayakhader, Patel YK (1983) Composition and packaging of peda. Indian J Dairy Sci 36: 187-189

Vyawahare AS, Rao KJ (2011) Application of computer vision systems in colour evaluation of kunda: a heat desiccated dairy product. Int $\mathrm{J}$ Dairy Sci 6: 253-266

Wani SA, Kumar P (2014) Comparative study of chickpea and green pea flour based on chemical composition, functional and pasting properties. J Food Res Technol 2: 124-129

Yam KL, Papadakis SE (2004) A simple digital imaging method for measuring and analyzing color of food surfaces. J Food Engg 61: $137-142$ 